\title{
O TESTAMENTO AMOROSO MEDIEVAL E A QUERELA DA "BELA DAMA SEM MISERICÓRDIA"
}

THE MEDIEVAL TESTAMENT OF LOVE AND THE

QUARREL OF THE BELLE DAME SANS MERCY

Daniel Padilha Pacheco da Costa

Universidade Federal de Uberlândia

Uberlândia, MG, Brasil

ORCID 0000-0003-4947-1295

\section{Resumo}

Este artigo trata da imitação da forma testamentária pela poesia medieval, em particular pela lírica amorosa na França. Surgida em vernáculo no fim do século XIII como um desenvolvimento dos sermóes em verso chamados de Vers de la Mort, a forma do testamento poético foi adaptada, em meados do século XV, à lírica cortês pelos poemas pertencentes à querela literária da Belle Dame sans Mercy, de Alain Chartier. Durante todo aquele período, esses dois modelos foram parodiados por diferentes gêneros cômicos como, por exemplo, bestiários burlescos, farsas e sátiras. Os dois poemas longos em forma de testamento atribuídos ao poeta francês medieval François Villon sáo uma paródia da inteira estrutura e das personagens do testamento amoroso da época. Pretende-se mostrar que o Lais e o Testament de Villon assumem uma posiçáo clara naquela querela do lado dos detratores da bela dama sem misericórdia com vistas a criticar as inconstâncias do amor.

Palavras-chave: lírica cortês, paródia medieval, testamento amoroso, François Villon, A querela da Belle Dame sans Mercy.

\section{Abstract}

This paper discusses the imitation of the testament form by medieval poetry, in particular by the lyric poetry in France. Born in vernacular at the end of the thirteenth century as a development of verse sermons called Vers de la Mort, the form of the poetic testament was adapted, in the mid-fifteenth century, to the lyric poetry by the works belonging to the literary quarrel of the Belle dame sans merci, by Alain Chartier. Throughout this period, these two models were parodied by different comic genres, such as burlesque bestiaries, farces and satire.

\section{Résumé}

Cet article examine l'imitation de la forme testamentaire par la poésie médiévale, en particulier par la lyrique amoureuse en France. Née à la fin du XIII siècle en langue vernaculaire pour développer les sermons en vers appelés Vers de la Mort, la forme du testament poétique a été adaptée, au milieu du $X V^{e}$ siècle, à la lyrique amoureuse par les poèmes liés à la querelle littéraire sur la Belle Dame sans Mercy, d'Alain Chartier. Tout au long de cette période, ces deux modèles ont été parodiés par différents genres comiques tels que les bestiaires burlesques, les farces 
The two long wills attributed to the medieval French poet François Villon are a parody of the entire structure and characters of Testament of Love of the time. It is intended to show that the Lais and the Testament by Villon take a clear position on the side of the detractors of the beautiful lady without mercy in that quarrel, in order to criticize the fickleness of love.

Keywords: Medieval lyric, Parody, Testament of Love, François Villon, The quarrel of the Belle dame sans mercy. et les satires. Les deux poèmes longs en forme de testament attribués au poète médiéval français François Villon sont une parodie de la structure entière et des personnages du testament amoureux de l'époque. Ce travail vise à montrer que le Lais et le Testament de Villon sont clairement, dans cette querelle, du côté des détracteurs de la belle dame pour critiquer les inconstances de l'amour.

Mots-Clés: Lyrique courtoise, Parodie médiévale, Testament amoureux, François Villon, La querelle de la Belle Dame sans Mercy.

Item, donne aux amants enfermes, Sans le laiz maistre Alain Chartier François Villon

O Antigo e o Novo Testamento foram uma fonte inesgotável de inspiração para os poetas medievais. Um exemplo disso foi a criação em vernáculo do testamento poético no final do século XIII, que pode ser considerado como um sermão em verso no qual o poeta assumia o papel de pregador para glosar passagens sapienciais dos testamentos bíblicos. Esse modelo religioso foi progressivamente substituído pela imitação da forma do testamento jurídico, utilizada seja pela poesia burlesca, seja pela lírica amorosa do final da Idade Média. No século XV, o testamento foi adaptado pela lírica para representar a figura do amante martirizado pela bela dama sem misericórdia, no contexto da querela literária da Belle Dame sans Mercy, de Alain Chartier.

A imitação literária do testamento jurídico foi objeto do estudo realizado pela medievista Jacqueline Cerquiglini-Toulet: L'écriture testamentaire à la fin $d u$ Moyen Âge (1999). Entre os principais testamentos poéticos do final da Idade Média, devem ser incluídos o Lais e o Testament atribuídos ao poeta francês François Villon (1431-?). Desde o final do século XX, a crítica especializada tem cada vez mais insistido na vinculação de Villon à poesia burlesca. Em La soif de François Villon, Roger Dragonetti (1993, p. 127) defende que os testamentos de Villon parodiam o léxico, as formas e as tópicas do testamento amoroso por meio de uma "retórica autobiográfica". 
Embora os bens burlescos que constituem a indústria dos legados sejam basicamente paródicos, a imitação pelo Lais e pelo Testament do testamento amoroso desenvolvido na França na segunda metade do século XV também possui uma intenção grave. Pretende-se mostrar que, ao parodiarem a inteira estrutura do testamento amoroso da época e, em particular, a personagem do testador na pose de amante mártir, os testamentos de Villon tomam uma posição clara naquela querela literária sobre o poema de Alain Chartier do lado dos detratores da bela dama sem misericórdia. Nesse sentido, os testamentos de Villon constituiriam uma mistura indissociável do grave e do burlesco com vistas não apenas a divertir, como também a ensinar.

\section{O testamento como gênero autônomo}

Desde o final do século XII, foram escritos em vernáculo diversos poemas sobre a morte, que receberam a designaçáo de Vers de la Mort. Entre 1194 e 1197, o poeta Hélinand de Froidmont, que se tornou monge de Froidmont, escreveu Le Vers de la Mort. Entre 1250 e 1270, foi escrito Li Ver de le Mor, de Adam de la Halle, e, entre 1266 e 1271, Les Vers de la Mort, de Robert le Clerc d'Arras. Em todas essas composiçóes, o poeta assume o papel de pregador para glosar passagens sapienciais do Antigo e do Novo Testamento. Fundados no discurso religioso da época, esses poemas podem ser considerados como sermóes em verso.

Como o termo vers em francês é equívoco e pode designar tanto os versos quanto os vermes que devoram a carne, os títulos podem ser traduzidos como "versos da morte" ou "vermes da morte". Os Vers de la Mort dramatizam a transitoriedade dos bens temporais, segundo as tópicas literárias do contemptu mundi (desprezo pelo mundo), carnes computruere (corrupçáo da carne) e, sobretudo, vado mori (vou morrer). Construídos por meio de apóstrofes à Morte (personificada), os versos são "da" morte tanto em sentido objetivo quanto subjetivo, pois a Morte é não apenas a personagem principal, como também o lugar de enunciação do poeta.

Retomando esse lugar de enunciaçáo e encenando o poeta antes de morrer, a forma do testamento poético pode ser considerada um desenvolvimento dos Vers de la Mort. Le Testament Maitre Jehan de Meun, ${ }^{1}$ do mesmo autor da segunda parte do Roman de la Rose, ${ }^{2}$ foi escrito entre 1291 e 1296. O título desse sermão em verso não foi dado pelo próprio autor, Jeahn de Meun, mas pelos escribas (GALLARATI, 1978). Ele é sucedido por um codicilo de oitenta e oito versos composto em quadras de rimas planas, como o testamento. $\mathrm{O}$

$1 \mathrm{O}$ testamento de mestre Jean de Meun.

2 Romance da Rosa. 
codicilo é o diminutivo do termo latino codex (livro) e designa um anexo no qual eram efetuadas alteraçóes ou anulaçóes de um testamento real.

A imitação da estrutura jurídica de um testamento real é uma constante nos testamentos amorosos compostos na segunda metade do século XV na França, como será mostrado a seguir. A forma testamentária permite conferir verossimilhança ao lugar comum do vado mori, pois o poeta não assume, como nos Vers de la Mort, o papel de pregador para invocar a Morte (personificada), mas o papel de testador moribundo para deixar seus bens aos legatários. Em Le Testament Maitre Jehan de Meun, o poeta abandona a autoridade de pregador para assumir as características particulares de uma personagem real no papel de testador.

Antes de se transformar em um gênero autônomo, a forma do testamento já fora explorada pelos autores que compuseram os poemas narrativos em vernáculo chamados de roman (romance). Uma das primeiras utilizaçóes do testamento poético pela literatura medieval em francês remonta ao Roman d'Alexandre, ${ }^{3}$ de Alexandre de Paris, escrito por volta de 1185 . Esse poema narrativo é a mise en roman (tradução em vernáculo) da vida do célebre imperador Alexandre, o Grande, cujas primeiras versōes foram escritas em grego no século III d.C. A vida de Alexandre é, em sua maior parte, narrada em terceira pessoa, como o gênero da história, do qual a vita (vida) é um subgênero.

No Roman d'Alexandre, o célebre imperador da Macedônia é associado à figura de Cristo onipotente. No quarto livro, Alexandre realiza uma ceia com sua corte toda reunida quando é envenenado por dois servos. A cena retoma elementos da "última ceia" de Cristo, identificando seus dois servos à figura histórica de Judas (ALEXANDRE DE PARIS, 1994, p. 782). Imediatamente depois de ser envenenado, o imperador inicia a narraçáo de seu testamento. No final do Roman d'Alexandre, o testamento de Alexandre é narrado em primeira pessoa pelo próprio imperador moribundo.

Para recompensar os serviços prestados pelos doze pares de França em suas numerosas conquistas, Alexandre partilha as terras conquistadas ao longo de sua vida. ${ }^{4}$ As fórmulas jurídicas "eu dou, eu lego" encarnam no presente da enunciaçáo as últimas vontades do testador. Os diversos bens legados por Alexandre amplificam sua generosidade, considerada como a maior virtude de um rei. Composto no gênero do Miroir des Princes, ${ }^{5}$ o Roman d'Alexandre

3 Romance de Alexandre.

4 Alexandre designa os doze pares pelos seus nomes próprios e, cada vez que faz um legado, lembra os serviços prestados pelo legatário ao imperador. Alexandre lega as terras conquistadas aos doze pares: depois de confiar a mulher a Pérdicas, Alexandre lega: a Grécia e a Macedônia ao próprio Pérdicas; o Egito a Tholomeu; a Pérsia a Clin; a Núbia da Arcágia a Emenidus; a Índia Maior a Aristeu; a Síria a Antiochus; a Cilícia a Antigonus; a Cesária a Filote; a Alenia e a Esclavônia a Licanor; a Hungria e o reino de Ansoi a Festion; Cartage a Aridès; a Armênia a Caulus da Macedônia (ALEXANDRE DE PARIS, 1994, p. 762-776).

5 Espelho dos Príncipes. 
caracteriza a personagem do imperador por meio das virtudes dignas de serem emuladas pelos futuros reis como, por exemplo, as virtudes teologais e cardinais. Alexandre cumpre com os legados as obrigaçóes terrenas e sua alma pode ir para o Paraíso. ${ }^{6}$

No Roman d'Alexandre, o testamento narrado em primeira pessoa pelo imperador conclui o relato de sua vida em terceira pessoa pelo poeta. Há uma oposição entre as duas estruturas narrativas, pois a vida dispóe linearmente a sucessão de eventos de uma existência, enquanto a escrita testamentária dispersa ao bel prazer os bens acumulados durante a mesma. Como narração da vida de uma personagem real, o gênero do testamento permanece associado ao gênero da vida. No entanto, ao se tornar um gênero autônomo no final do século XIII, a forma do testamento poético passa a prescindir de um contexto narrativo, pois fixa o momento derradeiro da vida do testador e enuncia no presente da narração suas últimas vontades.

Para suprir a necessidade de um contexto narrativo, a forma do testamento poético procura oferecer, antes do início dos legados e das disposiçôes finais, um exórdio contendo elementos sobre a vida do testador. O testamento poético - entendido como gênero autônomo enunciado basicamente em primeira pessoa por uma personagem real ou fictícia no papel de testador - é, com frequência, precedido por uma introdução (como, por exemplo, uma confissão ou um lamento) que permite contextualizar a causa da morte do testador e da escrita de seu testamento. Como será visto a seguir, esse contexto também pode ser oferecido por outros poemas sobre as mesmas personagens representadas no testamento.

\section{A querela da bela dama sem misericórdia}

O gênero do testamento foi adaptado à lírica amorosa a partir de meados do século XV na França, no contexto da querela literária da bela dama sem misericórdia. O poema inaugural da querela, a Belle Dame sans Mercy, ${ }^{7}$ foi escrito em 1424 por Alain Chartier. O poema narra a requête d'amour (demanda amorosa) de um jovem amante a uma bela dama. Antes de narrar em discurso direto o diálogo entre os dois protagonistas da lírica cortês, Alain Chartier se volta para a própria situação de enunciação do poeta. No exórdio da Belle dame, esse lamenta a morte recente de sua própria amada e, sem esperança de voltar a amar, enuncia sua renuntiatio amoris (renúncia ao amor):

\footnotetext{
6 Por fim, Alexandre ordena que o seu corpo seja transportado para Alexandria, no templo de Josué, onde deve ser enterrado sob uma lápide reservada a ele. As disposiçóes testamentárias para o enterro de seu corpo depois da morte finalizam o "testamento de Alexandre" (ALEXANDRE DE PARIS, 1994, p. 760).

7 Bela dama sem misericórdia.
} 
Je laisse aux amoureux malades

Qui ont espoir d'alegement

Faire chansons diz et balades

Chacun a son entendement

Car ma dame en son testament

Prist a la mort Dieu en ait l'ame

Et emporta mon sentement

Qui gist o elle soubz la lame

(CHARTIER, 2003, p. 18). ${ }^{8}$

Nessa estrofe, o poeta deixa para os outros amantes compor poemas, como cançóes, ditos e baladas. Em francês médio, o verbo "deixar" (laisser) é equívoco e significa tanto "abandonar" quanto "legar". O verbo laisser condensa o ato de abandono da atividade poética e, portanto, sua renúncia ao amor. A morte precoce de sua amada náo apenas a impediu de deixar seu testamento, mas ainda levou consigo o sentimento amoroso do poeta. Invadido pela tristeza depois da morte de sua amada, ele perdeu toda esperança no amor. Assim, ele lega e abandona àqueles que possuem o sentimento amoroso a tarefa de compor poemas.

A identidade entre a renúncia ao amor e a renúncia à poesia é um lugar comum da lírica cortês da época. $\mathrm{O}$ sentimento amoroso pode ser entendido náo apenas como o afeto presente na interioridade do poeta, mas também como sua própria expressão objetiva sob a forma do poema, que é entendido como instrumento imprescindível do serviço amoroso. Imitação do sentimento amoroso do poeta por uma dama, a lírica cortês pode ser definida pela sinonímia entre a composição poética e o serviço amoroso, como afirma Zumthor (1975). Retomando a elegia latina, a lírica amorosa se funda na polissemia do termo amor, que designa tanto o sentimento amoroso quanto o poema que o manifesta.

Depois de sua renúncia ao amor, o poeta narra a demanda amorosa do jovem a sua amada durante um baile. Ele cede a palavra em discurso direto aos amantes, que são escutados pelo poeta através de uma treille (trançado de videiras): "Assis, fors seullement les deulx/ Et n'y avoit aultre destour/ fors la treille entre moy et eulx" (CHARTIER, 2003, p. 28). ${ }^{9}$ Alternando a cada estrofe a enunciação em primeira pessoa do amante e da dama, aquele busca convencê-la de seu amor, enquanto esta lhe opóe as resistências prescritas pela castidade. A personagem da bela dama sem misericórdia constitui um lugar comum da lírica amorosa desde as cançóes dos trovadores provençais.

8 Deixo ao amante apaixonado/ Que espera alívio ao tormento/ Criar canção, dito e balada/ Conforme o seu entendimento/ Pois levou o testamento/ Consigo a amada defunta,/ Junto com meu sentimento/ Que jaz com ela sob a tumba (tradução nossa).

9 Sentados sozinhos os dois/ Nenhum obstáculo havia entre nós/ Senão um traçado de videiras (tradução nossa). 
A dama é descrita segundo as tópicas do gênero demonstrativo. Nas descriçōes dessa personagem na lírica cortês da época, era comum associar à beleza física e à nobreza de nascimento da dama suas virtudes morais. As qualidades visíveis no seu corpo e na sua posição hierárquica constituíam uma metáfora de seus atributos morais (justiça, temperança, castidade e misericórdia). $\mathrm{Na}$ descrição da bela dama, no entanto, não há correspondência completa, mas oposição parcial entre as qualidades físicas ou exteriores e as morais, pois o poeta opóe à beleza física e nobreza de nascimento a crueldade moral da dama, segundo o dualismo cristáo entre o externo e o interno.

A descriçâo da série de qualidades físicas ou exteriores da dama visa ressaltar sua crueldade. $\mathrm{O}$ amante ignora esse vício moral de sua amada e, acreditando na aparência enganosa de um amor verdadeiro, descobre tarde sua verdadeira natureza, colocando-se em dangiers (perigo). Uma das diversas personagens alegóricas da casuística amorosa representada pelo Roman de la Rose, o perigo designa a possibilidade de colapso do amante incapaz de suportar as duras provas submetidas pela dama a seu serviço amoroso, segundo a série de metáforas guerreiras adaptadas ao vocabulário cortês.

A Belle dame não imita o sentimento amoroso do poeta pela dama, como acontece na maior parte dos poemas líricos da época. Narrada pelo poeta em luto, a demanda amorosa é preenchida pela melancolia do poeta que, ainda que implicitamente, permanece presente por trás do diálogo como intermediário entre a demanda amorosa e o público. A narração da demanda amorosa é influenciada pelo luto do próprio poeta. Latente durante todo o poema na narraçáo pelo poeta do diálogo entre o amante e a dama, o desespero do amante com a impossibilidade do amor redunda em seu suicídio no final do poema.

A Belle dame pretende produzir a piedade do público pela personagem do amante mártir, que morre (literalmente) de amor pela bela dama sem misericórdia. Da mesma forma que o testamento religioso do final do século XIII, o testamento amoroso não visa apenas emocionar, como também ensinar. A personagem da bela dama serve como contraexemplo ao preceito da misericórdia, ensinado pelas artes de amor da época. Esse caráter exemplar do poema é explícito na exortação final do poeta que, depois de anunciar o trágico desfecho, assume novamente a primeira pessoa da enunciação para exortar o público feminino:

Et vous dames et demoyselles

En qui honneur naist et s'assemble

Ne soyés mie si cruelles

Chacune ne toutes ensemble

Que ja nulle de vous ressemble

Celle que me oyés nommer cy 
C'on peut appeler se me semble

La belle dame sans mercy

(CHARTIER, 2003, p. 82). ${ }^{10}$

A Belle dame foi imitada por diversos poetas do século XV, em uma querela literária opondo os defensores e os detratores da personagem da bela dama sem misericórdia. Acusa a bela dama de crueldade a Accusation contre la Belle Dame sans Mercy, ${ }^{11}$ de Baudet Herenc, que, escrito em 1432, também foi intitulado o Parlement d'Amours e Le jugement de la Belle dame sans merci. Também a acusam os dois poemas de Achille Caulier: La cruelle femme en Amour ${ }^{12}$ (também chamado Le jugement de la Belle dame sans merci) e L'Hospital d'Amours, ${ }^{13}$ escritos entre 1425 e 1441 . Como foi visto acima, o próprio Alain Chartier pode ser incluído do lado dos detratores da personagem da bela dama sem misericórdia.

Em Les erreurs du jugement de la Belle dame sans merci, ${ }^{14}$ os herdeiros da dama protestam contra o julgamento que redundou em sua morte. Nesse poema, no entanto, a crítica à crueldade da bela dama também está presente, embora a punição reservada a ela seja considerada excessiva. Entre os argumentos utilizados pelos seus herdeiros, há uma menção ao testamento deixado pelo amante depois da recusa daquela, no qual este não a acusa de nada e perdoa a todos (PIAGET, 1904). No anônimo La dame loyale en Amour, ${ }^{15}$ escrito no século XV, o poeta a defende diante do tribunal do amor contra a acusação de ter cruelmente frustrado as esperanças do amante. Um dos argumentos utilizados pelo poeta contra a acusação de crueldade é sua "lealdade a outro amante" (CHARTIER et al., 2003, p. 222).

A personagem do amante em luto pela morte de sua amada, utilizada na Belle dame, foi adaptada à forma do testamento poético por La confession et testament de l'amant trespassé de deuil, ${ }^{16}$ de Pierre de Hauteville, escrito por volta de 1447. Nesse que pode ser considerado como o modelo do testamento amoroso na época, o amante lânguido depois da morte de sua amada redige em primeira pessoa seu testamento antes de morrer. Composto por sextinas de decassílabos com duas rimas, o testamento amoroso de Hauteville retoma o

10 E você, donzela ou dama/ Que a honra nutra e reúna/ E de cruel evite a fama/ Dada a todas ou a só uma/ A fim de que nenhuma/ Por toda a cidade/ Seja chamada de "uma/ Bela dama sem piedade" (tradução nossa).

11 Acusação contra a Bela dama sem misericórdia.

12 A mulher cruel no amor.

13 Hospital do Amor.

14 Os erros do julgamento da bela dama sem misericórdia.

15 A dama leal no Amor.

16 Confissão e testamento do amante morto de dor. 
exórdio da Belle dame e apresenta a personagem do amante em luto no papel de testador, como afirma o incipit: "Je, povre amant, en amours maleureux" (HAUTEVILLE, 1986, p. 50). ${ }^{17}$

Em La confession et testament, o amante mártir confessa seus pecados (os sete pecados capitais e os pecados dos cinco sentidos), os quais são absolvidos pelo padre, depois de um diálogo entre as personagens do amante e do padre. No desenvolvimento, o testador realiza seus legados e deixa o amor a todos os tipos de amantes, ${ }^{18}$ segundo a ambiguidade do verbo laisser como legar e abandonar, explorada no exórdio da Belle dame. Por fim, o amante pede perdão, recomenda a alma a Deus e lega seus bens aos herdeiros da amada, para que rezem pela alma dela. Em La confession et testament, a renúncia ao amor é, ao mesmo tempo, uma despedida da vida, como evidencia o explicit: "Adieu, jamais ne vous verray/ Je vous recommande mon ame" (HAUTEVILLE, 1982). ${ }^{19}$

Em dois manuscritos (HAUTEVILLE, 1986), o testamento de Pierre de Hauteville é antecedido por La complainte de l'Amant trespassé de duei ${ }^{20}$ e seguido por L'Inventaire des biens demourez du décès de l'amant trespassé de dueil, ${ }^{21}$ escritos entre 1441 e 1446 . Composta por dezenove estrofes de dezesseis decassílabos com duas rimas, La complainte foi escrita para servir de introdução ao testamento e permite explicitar a razão que levou o amante a escrever seu testamento. O lamento do poeta desesperado depois da morte de sua amada é uma elegia fúnebre dirigida à Morte (personificada).

Composto por quadras de rimas cruzadas, L'Inventaire desempenha a função de codicilo de La Confession et testament, pois permite concluí-lo com um retrato do amante morto de dor. L'Inventaire é enunciado por um escriváo que, depois da morte do amante, enumera os bens deixados depois de sua dispersão física. O escrivão menciona (HAUTEVILLE, 1986, p. 70), entre os livros encontrados no interior da biblioteca deixada pelo amante, alguns poemas pertencentes à querela literária da bela dama sem misericórdia como, por exemplo, "La Belle Dame sans Mercy e L'Hospital d'Amours". Os três poemas podem ser considerados partes interligadas de uma única obra representando o destino trágico da personagem do pobre amante depois da morte de sua dama.

$17 \mathrm{Eu}$, pobre amante, infeliz no amor (tradução nossa).

18 Entre os diferentes tipos de amantes, estão os pobres, gravemente doentes, ardentes, sofredores, prisioneiros, pobres indigentes, galantes gentis, jovens, temerosos, atônitos, desassossegados, pensativos e nobres vassalos.

19 Adeus, não vos verei nunca mais/ E vos recomendo minha alma (tradução nossa).

20 Lamento do amante morto de dor.

$21 \mathrm{O}$ inventário dos bens deixados depois da morte do amante morto de dor. 
A utilização da forma do testamento por Pierre de Hauteville permite fundir as duas personagens masculinas do poema de Alain Chartier: o poeta em luto e o amante mártir. $\mathrm{Na}$ Belle dame, o poeta em luto narra, depois de renunciar ao amor, a demanda amorosa do amante mártir a sua dama, enquanto que, no testamento de Pierre de Hauteville, o próprio poeta assume a personagem do amante, que morre de dor não por causa da rejeição da amada, mas por causa de sua morte. Por pressupor desde o início a morte da amada, esse testamento não assume uma posição definida na querela da bela dama sem misericórdia. François Villon, ao contrário, utiliza seus testamentos amorosos para intervir nessa querela, como será visto a seguir.

\section{Os dois testamentos de François Villon}

A paródia da forma testamentária foi realizada por diversos gêneros cômicos em vernáculo, como bestiários burlescos, farsas e sátiras. $\mathrm{Na}$ Idade Média, são retomados os testamentos burlescos que, escritos desde a antiguidade, são enunciados por animais como, por exemplo, testamentos de porcos, asnos e mulas. No Testament de l'âne, ${ }^{22}$ de Rutebeuf, o asno deixa um saco de dinheiro para o bispo. Rutebeuf satiriza a avareza dos bispos, que constituía um lugar comum na época, retomando a sátira contra avareza como o vício de servidão ao dinheiro realizada, por exemplo, no Roman de la Rose. A crítica à avareza é frequentemente realizada nos testamentos, que caracterizam os legatários como pessoas interessadas pelos bens do testador.

No teatro burlesco medieval, é comum encontrar paródias da forma testamentária, como, por exemplo, o Testament de Pierre Pathelin. ${ }^{23}$ Esse testamento retoma a personagem do advogado charlatâo Pierre Pathelin, da Farce de Pierre Pathelin, para imitar o Testament, de Villon, mas, diferentemente desse, não é um monólogo dramático, e sim uma farsa com quatro personagens. A poesia palaciana também utilizou a forma testamentária para satirizar os vícios como, por exemplo, no Testament de la Guerre, ${ }^{24}$ de Jean Meschinot. Nesse testamento satírico, a Guerra (personificada) assume o papel de testador para deixar legados antes da morte. Ao realizar sua confissão, o testador dramatiza as consequências da Guerra.

Nos dois poemas longos em forma de testamento atribuídos ao poeta francês François Villon (1431-?), confluem estes três modelos do testamento poético medieval: o testamento jurídico, o amoroso e o paródico. Mais do que qualquer outro testamento poético da época, os dois testamentos de Villon imitam rigorosamente a estrutura de testamentos reais da época, como

22 Testamento do Asno.

23 Testamento de Pierre Pathelin.

24 Testamento da Guerra. 
demonstrou Van Zoest (1974). O desenvolvimento do Lais e do Testamento é constituído por sequências de legados introduzidos pela fórmula jurídica item ao início de cada estrofe. Essas sequências são construídas com base na enumeração dos bens deixados aos seus legatários, segundo a fórmula jurídica je laisse (eu deixo).

O desenvolvimento do Lais e do Testament é estruturado pela enumeraçáo dos bens deixados aos legatários pela personagem real de François Villon no papel de testador. No entanto, a insistência nas fórmulas jurídicas visa apenas intensificar o efeito irônico, pois os "bens" legados pelo célebre malfeitor da época são sempre falsos ou derisórios, escondendo insinuaçóes sobre os vícios dos seus beneficiários. Nas sequências de legados, Villon se refere a conhecidas personagens da época (como a amada, os amigos, a família, rivais e inimigos). Nos nomes próprios dos legatários de Villon, cujas identidades históricas foram reconstituídas por Pierre Champion (1913), figuram frequentemente seus atributos, segundo a tópica do nome.

O Lais é inteiramente constituído pela oitava quadrada, que é a forma poética utilizada pela Belle dame, de Alain Chartier. Ao longo das sequências de oitavas, o Testament intercala dezesseis baladas, se for tomada como referência a primeira edição de seu corpus, realizada por Pierre Levet (1489). A estrutura da balada foi fixada por Eustache Deschamps, antes de se tornar uma das formas mais utilizadas pela lírica amorosa do século XV, inclusive pelo próprio Alain Chartier. Assim, as formas poéticas utilizadas no Lais e no Testament de Villon são exatamente aquelas encontradas na lírica amorosa de Alain Chartier, em particular na Belle dame.

No Lais, Villon vincula a escrita de suas últimas vontades a sua experiência amorosa. O título do primeiro poema de Villon, o Lais, faz referência não apenas ao termo jurídico lais (legado), como também ao ato de laisser (deixar) a cidade de Paris. No Lais, o testador abandona as pessoas que conheceu e, em particular, a amada, como acontece no gênero do congé (despedida), oriundo de Arras e retomado por Adam de la Halle e Michault Taillevent. Os congés d'amour adaptaram à lírica amorosa esse gênero, a que pertence, por exemplo, La departie d'Amours en balades, de Charles d'Orléans (1992).

$\mathrm{Na}$ segunda estrofe, o testador utiliza imagens e metáforas utilizadas pela lírica cortês para introduzir a cena amorosa, como, por exemplo, a natividade e o carvão em brasa. Na Belle dame (CHARTIER, 2003), o carvão em brasa é utilizado como metáfora para o sentimento do jovem amante pela sua dama. Na lírica amorosa medieval, a contemplação da beleza física da dama frequentemente ocorre na primavera, a estação do renascimento, quando o sentimento amoroso nasce ao som dos pássaros e das fontes, segundo o lugar comum do locus amoenus (lugar ameno). Em um poema de Bernard de 
Ventadourn, por exemplo, a contemplação da amada é associada à natividade. ${ }^{25}$ No entanto, a cena descrita por Villon é de desolação:

En ce temps que j'ay dit devant

Sur le Noël, morte saison

Que le loups se vivent du vent

Et qu'on se tient en sa maison

Pour le frimas, pres du tison

Me vint ung vouloir de briser

La tres amoureuse prison

Qui faisoit mon cuer debriser

(VILLON, 1974, p. 11). ${ }^{26}$

Enquanto os lobos agonizam de fome, o poeta se aquece em casa junto à lareira durante o inverno, por volta do Natal. A casa com lareira protegendo o amante contra o inverno e os lobos famintos é utilizada como metáfora para a prisão amorosa. No rondó XV de Alain Chartier (1949, p. 57), o poeta assume a personagem do "pobre prisioneiro", segundo o lugar comum do serviço amoroso como prisão. Na estrofe citada, o Natal é chamado de "morta estação", pois, como nos congés d'amour, metaforiza o fim do amor (D’ORLÉANS, 1992, p. 241). No exórdio do Lais, a cena de desolação física permite introduzir a intenção do poeta de romper o serviço amoroso, associado ao lar que protege contra o frio. Assim, o poeta decide se expor ao frio e ao perigo porque seu coraçáo foi partido pela amada.

No exódio do Lais, a sedução da amada é expressa pelas metáforas visuais de "doulx regars et beaux semblans" (VILLON, 2000, p. 64). ${ }^{27}$ Essas metáforas fazem referência às personificaçóes de "Doce Olhar" e "Belo Semblante" que, oriundas do Roman de la Rose, foram retomadas pela poesia amorosa da época como, por exemplo, La Dame loyale en Amour. No entanto, o olhar por meio do qual Villon foi seduzido pela amada é qualificado de "traidor e duro": "Le regart de celle m’a prins/ Qui m’a esté felonne et dure" (VILLON, 2000, p. 62) ${ }^{28}$ Com efeito, Villon acusa sua amada, identificada à bela dama sem misericórdia do poema de Alain Chartier, de ser a responsável pelo seu colapso existencial, metaforizado pela sua exposição ao duro rigor do inverno.

25 "Pois parece a natividade o dia em que seus olhos espirituais me contemplam; porém faz ela assim tão raras vezes comigo, que um dia parece cem” (SPINA, 1991, p. 134).

26 Neste referido momento/ Pelo natal, morta estação,/ Quando os lobos vivem de vento/ E ficamos na habitação/ Pelo frio, junto ao tição,/ Deu-me vontade de quebrar/ A tão amorosa prisão/ Que o peito soia quebrantar (tradução nossa).

27 Tão doce olhar e belo semblante (tradução nossa).

$28 \mathrm{O}$ olhar dela me capturou/ Mas era traidor e duro (tradução nossa). 
No Lais, Villon assume a personagem do amante mártir: "Par elle meurs, les membres sains/ Au fort, je suis amant martyr/ Du nombre des amoureux saints" (VILLON, 2000, p. 62).$^{29}$ Essa personagem é típica da lírica amorosa da época, podendo ser encontrada em diversos poetas contemporâneos a Villon como, por exemplo, Charles d'Orléans. ${ }^{30}$ Nas passagens citadas, Villon explora a hipérbole, em locuçôes como "quebrar o coração" e "por ela morro". Ele não assume a personagem do poeta em luto, como o testador de La confession et testament, mas a personagem do amante rejeitado, como o jovem amante da Belle dame. O sofrimento provocado por essa rejeição é tal que Villon decide romper o serviço amoroso.

Incapaz de suportar as duras provas submetidas pela dama a seu serviço amoroso, Villon decide fugir de Paris e exilar-se em Angers, segundo o lugar comum do exílio como remédio ao amor. A justificativa para a fuga é o perigo de morrer (literalmente) de dor, como o amante da Belle dame. Colérico de ódio, Villon insinua que sua amada dedica a outro amante seus favores. Como foi dito acima, a referência a outro amante também é utilizada em La Dame loyale en Amour para defender a dama contra a acusação de crueldade. Villon utiliza o mesmo argumento para acusar sua amada náo apenas de crueldade, como também de trair seu serviço amoroso com outro.

Injustiçado e traído, o poeta amaldiçoa a amada, invocando a justiça divina: "Dieu en vueille ouirr ma clameur" (VILLON, 2000, p. 64). ${ }^{31}$ Ele cita as palavras de $\mathrm{Jó}^{32}$ - exemplo de homem justo que, depois de sofrer as duras provas da Fortuna, foi recompensado por Deus e seus inimigos foram punidos. Como não está certo de voltar do exílio, Villon assume o papel de testador para deixar seus legados, como La confession et testament. No testamento amoroso da época, o legado do coração é uma metáfora da renúncia do amor depois da morte da amada. Villon deixa seu coração para a amada, mas conclui seu primeiro legado com uma ironia, pedindo que Deus conceda a ela a misericórdia que esta não foi capaz de lhe conceder: "Mais Dieu lui en face mercy!" (VILLON, 2000, p. 66, grifo nosso)..$^{33}$

Escrito cinco anos mais tarde, o Testament também é enunciado pela personagem de Villon no papel de testador, mas esse não é mais jovem, como no poema anterior. Nas quatorze estrofes do Testament que se seguem aos

29 "E em membros sãos, morro, um dos tantos/ amantes mártires a vir/ no rol dos amorosos santos" (tradução de Sebastião Uchoa Leite).

30 "Au fort martyr on me devra nommer/ Se Dieu d'Amour fait nuls amoureux saints" (D’ORLÉANS, 1992, p. 80); “Des amoureux sera moult haut assis/ Comme martir et treshonnoré saint" (D’ORLÉANS, 1992, p. 118); “Prisonnier suis, d’Amour martir" (D’ORLÉANS, 1992, p. 146).

31 Queira Deus ouvir meu clamor (tradução nossa).

32 "Domine, exaudi orationem meam, et clamor meus ad te veniat" (apud VILLON, 1923, p. 11).

33 Que Deus lhe seja misericordioso (tradução nossa). 
Regrets de la belle Heaülmière, Villon reflete sobre sua própria experiência amorosa na juventude e relembra a época em que rompeu o serviço amoroso, como foi visto no exórdio do Lais. Ele maldiz o amor e conclui que a dor provocada pela rejeição da amada é a causa de sua morte iminente. No Testament, Villon não está mais prestes a fugir da cidade, como no Lais, mas está prestes a morrer de dor, como o amante martirizado pela "Belle Dame sans Mercy" do poema homônimo de Alain Chartier.

$\mathrm{Na}$ Ballade de conclusion (Balada de conclusão), a ficção poética do Testament é encerrada com o convite ao público para o enterro do "pobre Villon" (povre Villon), que é descrito como o amante mártir da lírica amorosa da época. Como em La Confession et testament, o poeta pede que os convidados ao enterro estejam vestidos de vermelho - referência ao costume que prescreve que os padres se vistam de vermelho para rezar missas solenes aos santos mártires. No Testament, Villon assume novamente a personagem do amante mártir, como no Lais, ao jurar que morreu por amor - o juramento irônico "por seus testículos" brinca com a etimologia de testamento, do latim testis (testículos):

Icy clost le testament

Et finist du povre Villon

Venez a son enterrement

Quant vous orez le carrillon

Vestuz rouge com vermeillon

Car en amours mourut martir

Ce jura il sur son couillon

Quant de ce monde voult partir

(VILLON, 1987, p. 166). ${ }^{34}$

$\mathrm{Na}$ Ballade de conclusion, o poeta e a personagem do testador não coincidem mais, pois aquele não utiliza mais a máscara desssa, que já morreu. Da mesma forma que L'Inventaire, a Ballade desempenha a função de codicilo do Testament. O Lais e o Testament de Villon parodiam a inteira estrutura das três partes do testamento amoroso de Pierre de Hauteville. No entanto, a amada dos testamentos de Villon não está morta, como neste último, mas é cruel, como na Belle dame. A rejeição de sua amada é apresentada como a causa de sua fuga de Paris, no Lais, e de sua morte, no Testament. Os dois testamentos de Villon podem ser considerados como as duas partes de um único poema que, iniciado com o rompimento do serviço amoroso, é concluído pela morte de dor do poeta.

34 "Aqui se encerra o testamento/ Pelo pobre Villon deixado/ Vinde ao enterro quando lento/ Ouvirdes do sino o dobrado,/ Com roupa em vivo avermelhado/ Que ele é mártir de amor profundo/ Sobre o culhão tal foi jurado/ Quando quis partir deste mundo" (traduçáo de Afonso Felix de Sousa). 
Desde o final do século XX, a fuga de Villon para Angers no Lais foi considerada pela crítica como um sintoma do fim do amor cortês no declínio da Idade Média. Roger Dragonetti (1983, p. 598) interpretou essa fuga em sentido programático, como o abandono da "antiga tradição da retórica cortês". Mazzariol e Carminati retomaram essa interpretação: "Finisce qui la finzione dell'amante martire che si sottrae con la fuga a un destino di morte: [...] si consuma così la fine di una secolare tradizione della quale il poeta si spoglia per ricostituire "altrove" la sua ri-omanza, o nuova identità" (VILLON, 2000, p. 356)..$^{35}$ Dessa perspectiva, esse abandono - anunciado no Lais - expressaria de maneira aguda a crise daquela tradiçáa, crise essa cuja morte seria concretizada no Testament.

Procurou-se restituir os dois testamentos poéticos de François Villon ao contexto em que foram compostos na segunda metade do século XV na França. No Lais e no Testament, Villon retoma lugares comuns - a renúncia ao amor e o exílio como remédio ao amor - e personagens - o amante mártir e a bela dama sem misericórdia - utilizados pela lírica amorosa desde os trovadores provençais, como testemunha, por exemplo, a canção iniciada por Merces es perduta per ver, ${ }^{36}$ de Bernart de Ventadorn. Embora seus dois poemas longos parodiem a inteira estrutura do testamento amoroso da época, essa paródia não representa uma recusa completa da tradição poética medieval, representada pelo testamento amoroso (DRAGONETTI, 1993).

Diferentemente de La confession et testament, o Lais e o Testament tomam posiçáo definida naquela querela literária do lado dos detratores da personagem da bela dama sem misericórdia. A paródia realizada por Villon visa ridicularizar a personagem do amante mártir, incapaz de suportar a rigorosa disciplina imposta pelo serviço amoroso, bem como denunciar a crueldade e a volubilidade da personagem da bela dama sem misericórdia ao trair seu serviço amoroso com outro amante. Portanto, os dois poemas longos de Villon não deixam de perpetuar a tradição do testamento amoroso medieval, pois visam criticar, não o amor cortês enquanto tal, mas as diferentes formas de inconstância do amor.

35 Termina aqui a ficçáo do amante mártir que se subtrai com a fuga a um destino de morte: [...] consuma-se assim o fim de uma tradição secular da qual o poeta se livra para reconstituir "em outro lugar" seu romance, ou nova identidade (tradução nossa).

36 "Nấo há dúvida, a misericórdia está perdida - e eu sempre o ignorei; se nela, onde havia razōes para encontrá-la, não encontro, onde a buscarei? Ah! Como é difícil crer, depois que a viu, ser ela capaz de deixar morrer sem recurso a este pobre cativo que sem ela não pode viver! Desde que com minha dama não me podem valer as minhas solicitações, nem sua misericórdia, tampouco os direitos que tenho, nem lhe apraz o amor que the voto, mais nada lhe direi. E a ser assim, separo-me dela e ao seu amor renuncio; matou-me, e como morto lhe respondo; visto que ela não me detém, irei, miserável, em exílio, pelo mundo e sem rumo. Tristão, não tereis mais nada de mim, porque me vou desgraçado, não sei para onde; não mais haverei de cantar, à alegria e ao amor renunciarei" (SPINA, 1991, p. 147). 
ALEXANDRE DE PARIS. Le Roman d'Alexandre. Paris: Librairie Générale Française, 1994.

CERQUIGLINI-TOULET, J. L'écriture testamentaire à la fin du Moyen Âge: identité, dispersion, trace. Oxford: Legenda, 1999.

CHAMPION, P. François Villon, sa vie et son temps. Paris: Champion, 1913. t.1.

CHARTIER, A. La Belle Dame sans Mercy et les poésies lyriques. Edité par Arthur Piaget. Genebra: Droz, 1949.

CHARTIER, A.; HERENC, B.; CAULIER, A. Le Cycle de La Belle Dame sans Mercy: une anthologie poétique du XVe siècle. Trad. David F. Hult et Joan E. McRae. Paris: Champion, 2003.

DRAGONNETTI, R. Le contredit de François Villon. Modern Language Notes, Baltimore, v. 98, n. 4, p. 594-623, 1983. Disponível em: https://doi. org/10.2307/2905896

DRAGONNETTI, R. La soif de François Villon. In: DERENS, J. DUFOURNET J., FREEMAN M. Villon: hier et aujourd'hui. Paris: La Bibliothèque de la Ville de Paris, 1993, p. 123-136.

D’ORLÉANS, C. Ballades et Rondeaux. Paris: Librairie Générale Française, 1992.

GALLARATI, S. B. Nota bibliografica sulla tradizione manoscritta del Testament di Jean de Meun. Revue Romane, Amsterdam, v. 13, n. 1, p. 2-35, 1978.

GUILLAUME DE LORRIS; JEAN DE MEUN. Le Roman de la Rose. Paris: Librairie Générale Française, 1992.

HAUTEVILLE, P. La confession et testament de l'amant trespassé de deuil. Edité par Rose M. Bidler, Otawa, Ceres, 1982.

HAUTEVILLE, P. La Complainte de l'amant trespassé de dueil. L'Inventaire des biens demourez du décès de l'amant trespassé de dueil. Edité par Rose M. Bidler. Montréal: CERES, 1986.

JEAN DE MEUN. Testamento e Codicillo: etica, cultura, politica nella Parigi medievale. Editione de S. Buzzetti Gallarati. Fiesole, 1996.

RUTEBEUF. Testament de l'Asne. In: RUTEBEUF. Cuvres complètes de Rutebeuf. Publié par Edmond Faral et Julia Bastin. Paris: Picard, 1977, p. 104-113.

PIAGET, A. La belle dame sans merci et ses imitations. Romania, Paris, t. 33, n. 130, p. 179-208, 1904. 
SPINA, S. Lirica trovadoresca. São Paulo: Edusp, 1991.

RYCHNER, J. Du Saint-Alexis à François Villon: études de littérature médiévale. Genève: Droz, 1985.

VAN ZOEST, A. J. A. Structures de deux Testaments fictionnels - Le Lais et le Testament de François Villon. Paris-La Hague: Mouton, 1974.

VILLON, F. Euvres. Edité par Louis Thuasne, Paris, A. Picard, 1923. t. II.

VILLON, F. Le Testament Villon. Edité par Jean Rychner et Albert Henry. Genebra: Droz, 1974. t. I.

VILLON, F. Testamento. Tradução de Afonso Felix de Sousa. Belo Horizonte: Itatiaia, 1987.

VILLON, F. Poesia. Tradução de Sebastião Uchoa Leite. São Paulo: Edusp, 2000.

VILLON, F. Opere. Traduzione di Emma Stojkovic Mazzariol e Attilio Carminati. Milano: Mondadori, 2000.

ZUMTHOR, P. Le je de la chanson et le moi du poète. In: ZUMTHOR, P. Langue, texte, énigme. Paris: Le Seuil, 1975, p. 181-196.

Daniel Padilha Pacheco da Costa. Professor do curso de Tradução e do Programa de Pós-graduação em Estudos Literários do Instituto de Letras e Linguística da Universidade Federal de Uberlândia (UFU). Doutor pelo Departamento de Letras Modernas da USP (Programa de Estudos Linguísticos, Literários e Tradutológicos em Francês), com um estágio doutoral de um ano na Université Paris-Sorbonne (Paris IV). Graduado em Filosofia pela Universidade de São Paulo e em Letras Francesas pela Université Sorbonne Nouvelle (Paris III), com proficiência em Língua Francesa. Integrante de grupos de pesquisa sobre tradução e antiguidade clássica. Tradutor profissional do francês, com ênfase em Filosofia Francesa Contemporânea.

E-mail: dppcosta@hotmail.com 


\section{ERRATA}

https://dx.doi.org/10.1590/1517-106X/212238254errata

No artigo: O testamento amoroso medieval e a querela da Belle Dame sans Mercy. Alea, v.21, n.2, p.238-254, 2018. DOI 10.1590/1517-106X/212238254

Na página 238:

No título, onde se lia:

O testamento amoroso medieval e a querela da Belle Dame sans Mercy Le testament amoureux médiéval et la querelle de La Belle Dame sans Mercy

Leia-se:

O testamento amoroso medieval e a querela da "Bela dama sem misericórdia" The medieval testament of love and the quarrel of the Belle dame sans mercy 